\title{
The Soviet energy balance
}

\author{
Philip Hanson surveys Soviet energy resources and assesses \\ the USSR's energy policy as a factor crucially affecting the \\ prospects for economic growth
}

\begin{abstract}
F ALL the countries in the world, the Soviet Union has the most impressive known endowment of nonagricultural natural resources. This is as true of fuel as it is of raw materials. In addition to being the world's second largest gold producer and a leading producer of almost all the useful mineral raw materials, the USSR has all the energy options available from domestic sources: wood, peat, oil shale, coal, oil, natural gas, hydro power and uranium.
\end{abstract}

In the past few years, however, when energy supplies have become a crucial consideration in economic policy everywhere, the Soviet energy balance has begun to seem precarious. Nobody disputes that the Soviet Union still has vast "potential", or geologically indicated, reserves of the major fuels. Beyond that, however, the Soviet energy position is open to a variety of assessments.

One problem is reserves. The extent of proved reserves, on definitions comparable to those used in the West, is not clearly established. Another problem is costs. The main areas from which increases in fuel supply can come are east of the Urals. Extraction costs in the new oil, gas and coal fields of Siberia vary greatly: for some deposits costs are quite low, for others rather high. But the social overhead costs of bringing roads, housing and amenities to these areas are generally high. Once the fields are being exploited, the cost of moving Siberian energy to the user (by oil and gas pipelines, rail shipments of coal and high-voltage electricity transmission) are generally very high. The alternative of moving the users to the energy supplies is also costly. These high costs are attributable mainly to the harsh natural conditions of most of the area-notably blizzards, permafrost and swamps.

Costs and reserves are not the only contentious issues. There is a good deal of uncertainty about the demand side. How fast will Soviet energy consumption rise in the next five or ten years? Will the Soviet Union remain a net exporter of energy in general and of oil in particular? What are the chances of the West obtaining significant energy supplies from the USSR? The wide spread and frequent revisions of recent

Philip Hanson is at the Centre for Russian and East European Studies, University of Birmingham. forecasts of Soviet energy consumption in 1980 do not inspire much confidence in such forecasts. And the implications for Soviet energy supplies to the West also depend on future Soviet policies in the supply of energy to Eastern Europe, which are not easy to predict beyond 1980 .

There is another problem in any assessment of Soviet energy prospects, and this concerns technology. How badly do the Russians need Western technology in order to increase their oil, gas and coal production? Do they need it enough to ensure that some of the more grandiose East-West cooperation projects in Siberia will actually materialise?

Those are the main questions. Some can be answered with reasonable confidence; others are wide open. The accompanying tables summarise recent and planned developments in Soviet energy supply in the 1970 s. The plans for 1976-1980 envisage some slowdown in the growth of the primary fuels, except for coal. With petroleum output in some of the older fields in the European USSR expected to fall, this is not too surprising. Oil and gas production in West Siberia (Tomsk and Tyumen provinces) is the main source of growth in the immediate future. West Siberia produced 148 million tonnes of oil and 38,000 million cubic metres of natural gas in 1975 and these figures are

Table 1 Soviet Energy Production

\begin{tabular}{lrcccc}
\hline & $\mathbf{1 9 7 0}$ & $\begin{array}{c}\text { Annual average } \\
\text { growth rate (\%) }\end{array}$ & $\mathbf{1 9 7 5}$ & $\begin{array}{c}\text { Annual average } \\
\text { growth rate (\%) }\end{array}$ & $\begin{array}{c}\text { 1980 plan } \\
\text { (mid-point of range) }\end{array}$ \\
Oil $\left(10^{6}\right.$ tonnes) & 353 & 6.9 & 491 & 5.2 & 630 \\
$\begin{array}{l}\text { Natural gas }\left(10^{9} \mathrm{~m}^{3}\right) \\
\text { Coal }\left(10^{6} \text { tonnes }\right)\end{array}$ & 198 & 7.9 & 289 & 7.7 & 418 \\
\hline $\begin{array}{l}\text { Total energy } \\
\left(10^{6} \text { tonnes sfe }\right)^{1}\end{array}$ & 1,238 & 6.0 & 1,656 & 5.5 & 800 \\
\hline Electricity $\left(10^{6} \mathrm{MWh}\right)$ & 741 & 7.2 & 1,038 & 5.6 & 2,158 \\
\hline
\end{tabular}

${ }^{1}$ Standard fuel equivalent in metric tonnes of 7,000 kilocalories.

Source: Soviet plan fulfilment reports and draft directives for the 1976-1980 plan, except that total energy production figures are author's own estimates. 1980. the next few years, however, seem to deceleration in the growth of oil and gas production. One additional conerves by V. Shashin, the Minister for the proved have recently been less than the has $37 \%$ of the world's oil-bearing land. But exploration and proving costs hetween potential US estimate is that the USSR has a relatively modest $12.1 \%$ of the world's for the other fuels are not secret, Soviet proved, semi-proved and probable gas reserves (Soviet categories $\left.\mathrm{A}+\mathrm{B}+\mathrm{C}_{1}\right)$ at the end of 1974 is sents 92 years' production at 1974 rates the difficulties of exploiting these eserves are considerable, and producnas fallen behind plan. nuclear power. Major increments to oal output are planned from the whose low-cost coal, produced in large part by open-cast and strip mining, can be effectively used as a fuel for thermal

Table 2 Contribution of Primary Sources of Energy to Total Energy Production ( $\%)^{1}$

\begin{tabular}{|c|c|c|c|}
\hline Energy source & 1970 & 1975 & 1980 plan \\
\hline $\begin{array}{l}\text { Oil } \\
\text { Natural gas } \\
\text { Coal } \\
\text { Peat, oil shale, wood } \\
\text { Hydro } \\
\text { Nuclear }\end{array}$ & $\begin{array}{r}41 \\
19 \\
35 \\
4 \\
1 \\
\frac{1}{2}\end{array}$ & $\left\{\begin{array}{l}42 \\
21 \\
30 \\
7\end{array}\right.$ & $\left\{\begin{array}{l}42 \\
23 \\
26 \\
10\end{array}\right.$ \\
\hline
\end{tabular}

${ }^{1}$ Because of rounding, columns do not all sum to 100 .

Source: Author's estimates on the basis of the sources used in Table 1. 


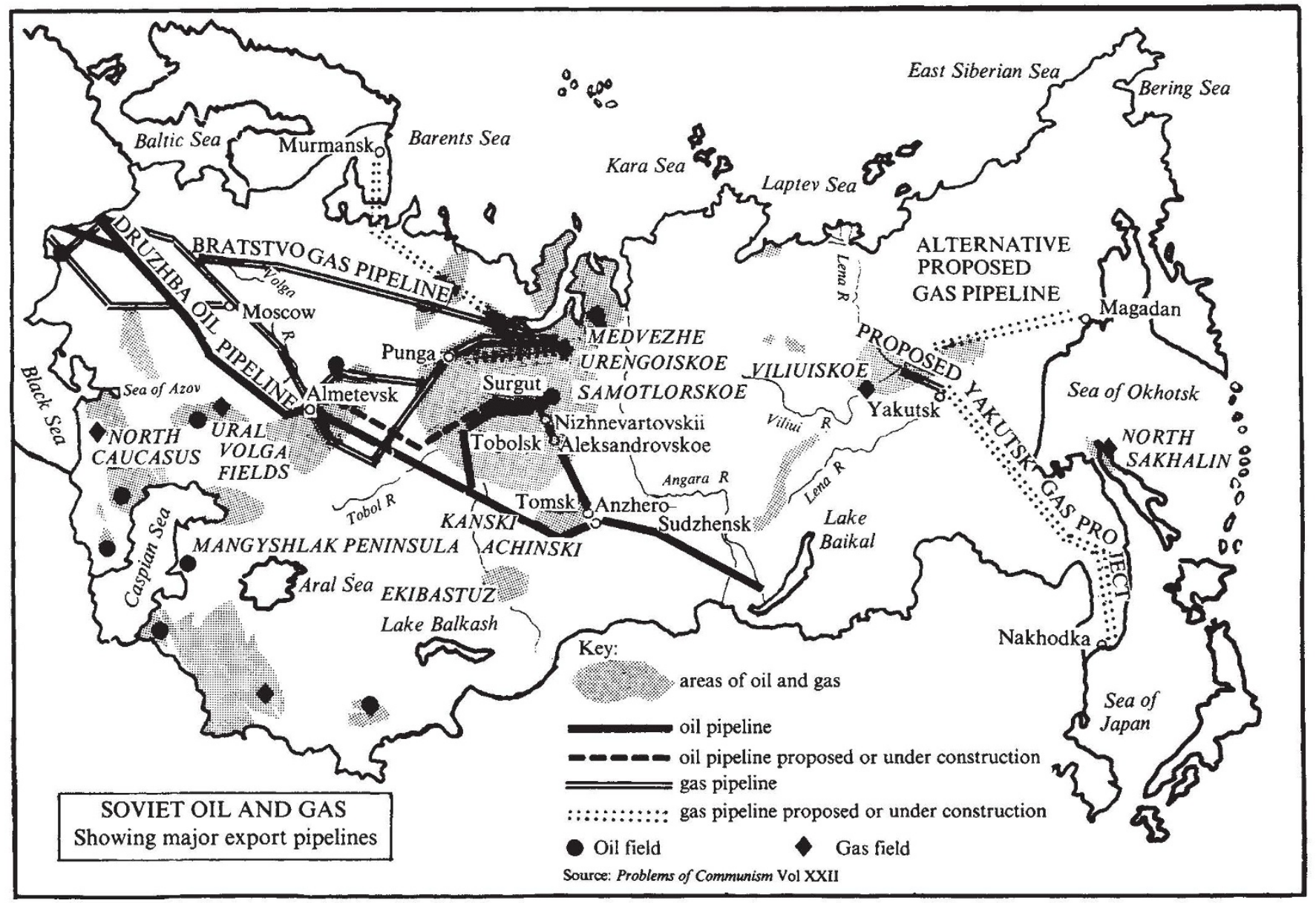

power stations in the Urals and elsewhere. At the same time the Five Year Plan requires the construction of nuclear power stations in the European USSR and the Urals with total capacity of 13-15 mullion $\mathrm{kW}$, out of a construction programme of 67-70 million $\mathrm{kW}$ of new generating capacity of all types. Soviet installed nuclear power capacity has hitherto been small-3.7 million $\mathrm{kW}$ at the end of 1974 compared to 30.4 million in the USA and a total of about 14 million in Western Europe-so this plan would increase the role of nuclear power stations considerably.

This shift in policy has been indicated in a number of Soviet sources over the past two years. It appears to be a response both to higher world energy prices following the Yom Kippur war and to previously unexpected costs and bottlenecks in Siberian oil and gas developments. In his report to the XXV Party Congress in February, Mr Kosygin put the change in quite striking terms: future increases in oil and gas output would be allocated to "technological" needs (for example, feedstocks for the chemical industry), rather than to electricity production. The latter will depend much more heavily on hydro and nuclear power and coal than had previously been planned.

It could well be that the Soviet planners now see energy supply as a bottleneck restricting Soviet economic growth. American recalculations of recent Soviet growth in terms comparable with the measurement of economic growth in the West show an annual growth rate of Soviet real GNP in the first half of this decade of $3.9 \%$. The plan for the latter half of the decade (of a 4.4 to $5.0 \%$ annual growth in net material product) probably implies something like a $3 \frac{1}{2} \%$ GNP growth rate. This is admittedly only a modest deceleration, and the plan targets that are finally approved may even show no deceleration at all. But in the light of postwar Soviet plans generally, the 1980 targets look a lot more modest than they do in relation to recent performance; it is likely that they reflect newly-perceived constraints of some severity.

In the early 1970s Soviet electricity and total energy production grew appreciably faster than total national output. In part this reflected the fact that the net export of energy grew in most of the past five-year period. It probably also reflected a tendency for energy consumption to rise somewhat faster than GNP. If Soviet energy consumption continues to rise slightly faster than GNP, the exportable surplus may not grow at all between 1975 and 1980.

A recent study by Jeremy Russell projects a Soviet energy surplus in 1980 of 200-250 million tonnes of conventional fuel equivalent; a surplus of the same order of size on that of 1975. For oil alone the surplus is likely to narrow. Russell's conclusion is that the Comecon group as a whole will still have a surplus of oil production over consumption in 1980 but that a Comecon oil deficit, that is, net imports, is likely fairly soon thereafter.

Soviet long-term oil delivery contracts to Eastern Europe up to 1980 have already been agreed. It is likely that in 1980 only 20-30 million tonnes of Soviet oil (according to Russell), or perhaps 35 million tonnes (according to the Brussels market research organisation, east-west), will be available to Western markets. The USSR itself might remain a small net exporter of oil, and some imported Middle East oil might be routed to Eastern Europe through Soviet pipelines.

The position could be quite different as far as natural gas is concerned. Russell projects an annual net Comecon export of natural gas-essentially Soviet natural gas-of perhaps 3050,000 million cubic metres a year in the early 1980s. Soviet natural gas is already being delivered by pipeline to Austria, Italy, West Germany and France, and Iranian natural gas is being piped through the USSR to West Germany, France and Austria. These 
are both long term deals and could involve natural gas supplies of the order of 20,000 million cubic metres a year to Western Europe in 1980. The Siberian gas deals that have been discussed with US and Japanese companies in recent years (the Yakutsk and North Star deals) are larger and considerably more problematic. They involve tanker deliveries of liquefied natural gas out of a Pacific coast port and Murmansk, respectively, at a total rate of perhaps 50,000 million cubic metres a year over 25 years. The commercial and political obstacles to the eventual implementation of these deals are formidable. On March 31, however, a Soviet-US-Japanese agreement on joint exploration of the Yakutsk gas deposits was signed, with credits of $\$ 25$ million each being contributed by the Japanese and US consortia.

The fact that this preliminary agreement has been signed despite all the obstacles indicates the strength of both Soviet and Western interests in the development of Siberian energy supplies. The Western interest requires no explanation, but the Soviet interest is less immediately comprehensible. Why mortgage substantial future energy outputs to the West when energy supplies already form a bottleneck to your own economic growth?

The answer seems to be that Soviet energy production can grow much faster if Western technology is used, and the gains should be enough to repay Western suppliers (in gas) and still have something left over for domestic needs. Soviet technical deficiencies are beginning to show up in a number of key areas. The items which the Russians are unable to produce domestically in sufficient quality and/or quantity in the near future include wide-diameter $(1220$ and $1420 \mathrm{~mm})$ oil and gas pipeline, pipeline compressor equipment, machinery for deep drilling and secondary oil recovery, submersible pumps, offshore rigs and a wide range of coal mining equipment. It is likely that at least three-quarters of the $20,000 \mathrm{~km}$ of wide-diameter oil and gas pipeline laid in 1971-1975 was imported Western pipe. Costly pipe imports continue: in January and February about $\$ 500$ million worth of new orders were placed in Italy, Japan and France.

The picture of pervasive East-West interpendence which these projects evoke is misleading, however. Soviet natural gas deliveries to West Germany provide less than $15 \%$ of West German natural gas consumption. The corresponding figure for the USA in the early 1980 s in the event (now remote) of both the North Star and Yakutsk projects going ahead has been put at about $10 \%$.

On the Soviet side, the best assessment seems to be that the Russians will obtain an increase in energy supplies sufficient to support a respectable economic growth rate by a mixture of policies: shifting towards fuels less efficient than oil, incurring very large domestic development costs in Siberia, making some use of Western machinery and know-how and perhaps importing significant amounts of Middle Eastern oil. Neither Soviet nor Western energy-supply problems are sufficiently awful to ensure peace on earth and goodwill between Moscow and Washington.

\section{BRITAIN}

\section{Wave energy on}

Research in Britain on alternative sources of energy took a step forward last week. Allan Piper reports

THE first real move towards exploiting one of Britain's unconventional energy sources has come with last week's announcement that the Department of Energy (DEN) is to spend $£ 1.01 \mathrm{mil}-$ lions on a 2-year feasibility study of wave-power devices. If the programme is successful further research could lead to the development of such devices to provide up to half of Britain's electrical energy requirements early next century.

News of the venture coincided with the publication of the latest annual report on UK offshore oil and gas resources, which gives estimates that proven reserves of North Sea oil have increased by almost a third over the past year. Although the report revises the production forecast for 1980 slightly downwards, the new estimates are seen as offering the prospect of Britain attaining self-sufficiency in energy by the end of the decade, at the same time providing a stopgap until alternatives such as the wave-power scheme also come on stream.

The decision to press ahead with work on wave power is based on a National Engineering Laboratory report identifying it as a particularly promising energy resource. Early measurements indicate that the amount of wave energy available around British coasts varies between 40 and $70 \mathrm{~kW}$ per metre. The most abundant supplies are offered off north-western Scotland, but areas around the Cornish coast also show considerable potential. One advantage of wave power over other novel energy resources is that the wintertime peak of supply will coincide with maximum consumer demand.

The feasibility study is to assess the relative merits of four possible devices. Three of them, including the "Salter Duck", are British designs; the fourth is Japanese. All use different methods of converting wave energy to a usable form. Each one will be studied at a one-hundredth scale by teams of academic and industrial scientists. While looking principally at operational efficiencies and seaworthiness under varying conditions, they will also estimate approximate costs for any further research and development leading to seagoing trials.

A support programme will cover the collection and analysis of wave data, the long term effects of prolonged wave action on the structures, anchoring and mooring problems, likely environmental and navigational effects of large-scale installations, and possible modes of power generation and transmission.
The Central Electricity Generating Board has already started research into ways of integrating the supply into the national grid system.

Commenting on the decision to proceed with wave-power research, Dr Walter Marshall, Chief Scientist at the DEN, said that his department would retain control over the research teams through its Harwell-based Energy Technology Support Unit. The bulk of the $£ 1$ million will go towards the principal research programme; it will not be spread equally, but $\mathrm{Dr}$ Marshall gave no clues as to whether any of the devices had yet emerged as a clear favourite.

Stressing that the programme represented only an early exploratory phase of wave-power research, Dr Marshall said that further development depends on the findings of the next two years. If all goes well a $10 \mathrm{MW}$ prototype should be in the sea by 1986 , with a full-scale model operating by the 1990 s, but $\mathrm{Dr}$ Marshall declined to forecast a firm date for commercial power production, as past estimates of time-scales on such major projects have generally been "hopelessly optimistic". He did say, however, that commercial installations could be operating during the next century, and DEN figures show that a 600 mile chain of devices around north-western Scotland could eventually provide about half of Britain's present electrical energy requirements even on conservative estimates. Individual devices, each up 